\title{
Lise Öğrencilerinde Beden Algısı ve Benlik Saygısı Arasındaki İlişkinin Medya ve Farklı Değişkenler Açısından İncelenmesi*
}

\author{
Relationship Between the Body Perception and Self-Esteem of the High School \\ Students in Terms of Some Variants and Media
}

\author{
Hilal ÖZBEY (iD), Dr. Öğr. Üyesi Mücahit GÜLTEKİN (iD2
}

\begin{abstract}
$\ddot{O} z$
Bu çalışmanın amacı lise öğrencilerinin benlik saygısı ve beden algısı düzeylerine düzenli takip edilen medya programı sayısı ve türü, sosyal medya hesap sayısı, günlük sosyal medyada geçirilen süre gibi medya ile ilgili değişkenlerin ve demografik değişkenlerin etkisini incelemektir. Araştırmanın örneklemini Konya ili Akşehir İlçesinde öğrenim gören 385 öğrenci oluşturmaktadır. Araştırmada veri toplama araçları olarak 'Rosenberg Benlik Saygısı Ölçeği' ve 'Beden Algısı Ölçeği' kullanılmıştır. Verilerin bilgisayar ortamında analiz edilmesinden sonra öğrencilerin benlik saygisı ve beden algisı düzeyleri arasında orta düzeyde negatif yönde anlamlı bir iliş̧ki olduğu tespit edilmiş̧ir. Öğrencilerin benlik saygısı ve beden algısı ölçeklerinden aldıkları puanlar ile cinsiyet, okul türü, aile türü, algılanan sosyo-ekonomik durum, günlük telefon/tablet kullanımı, sahip olunan sosyal medya profil sayısı, düzenli takip edilen dizi sayısı, en çok izlenilen program türü değişkenleri arasında anlamlı bir ilişkiye rastlanamamıştır. Öğrencilerin sosyo-ekonomik durumları ve günlük tablet/telefon kullanım süresi tek başlarına benlik saygısı arasında anlamlı bir farklılık bulunmuştur. Günlük tablet/telefon kullanım süresi arttıkça benlik saygısı azalmaktadır. Öğrencilerin diyet uygulama durumu ile benlik saygısı ve beden algısı düzeyleri arasında anlamlı bir farklılık saptanmıştır. Araştırma bulgularına göre diyet uygulayan öğrencilerin beden algıları daha olumsuz, benlik saygıları daha düşüktür. Bu konuda ergenle en yakın temas halinde olan ailelerin ve öğretmenlerin farklı çalışmalarda bulunarak ergenin benlik saygısının yükseltilmesi ve beden algısının daha olumlu olması sağlanabilir.
\end{abstract}

Anahtar Kelimeler: Ergen, benlik saygis1, beden algis1, medya, sosyal medya

Makale Türü: Araştırma

\begin{abstract}
The aim of this study is to examine the effects of demographic variables and media-related variables such as the number and type of media programs regularly monitored, the number of social media accounts, and the time spent on daily social media on the self-esteem and body perception levels of high school students. The sample of the study consists of 385 students studying in Akşehir, Konya. "Rosenberg SelfEsteem Scale" and "Body Image Scale" were used as data collection tools in the study. İt was determined that there is a moderately negative significant relationship between the students' self-esteem and body perception levels. Students' scores on self-esteem and body perception scales and gender, school type, family type, perceived socio-economic status, daily phone/tablet use, number of social media profiles owned, the number of regularly followed TV series are among the most watched program type variables. no meaningful relationship was found. A significant difference was found between the socio-economic status of the students and the duration of daily tablet/phone use alone self-esteem. Self-esteem decreases as the daily tablet / phone usage time increases. A significant difference was found between the dieting status of the students and their levels of self-esteem and body perception. According to the findings of the

\footnotetext{
* Bu çalışma, Afyon Kocatepe Üniversitesi Sosyal Bilimler Enstitüsü Eğitim Bilimleri Anabilim Dalında ikinci yazar danışmanlığında birinci yazar tarafından hazırlanan "Lise Öğrencilerinde Beden Algısı ve Benlik Saygısı Arasındaki İlişkinin Farklı Değişkenler Açısından İncelenmesi” adlı yüksek lisans tezinden yararlanılarak hazırlanmıștır.

${ }^{1}$ Hendek Özel Eğitim Uygulama Okulu 3. Kademe, Sakarya, hilalcingozoglu@gmail.com.

${ }^{2}$ Afyon Kocatepe Üniversitesi, Eğitim Fakültesi, mgultekin1@hotmail.com.
}

Atıf için (to cite): Soyad, A. (2021). Lise öğrencilerinde beden algisi ve benlik saygisi arasindaki ilişkinin medya ve farkli değişkenler açisindan incelenmesi. Afyon Kocatepe Üniversitesi Sosyal Bilimler Dergisi, 23(2), 429-441. 
research, body perception of the students on diet is more negative and their self-esteem is lower. Families and teachers can work on different studies to increase the self-esteem and body perception of the adolescent

Keywords: Adolescent, self-esteem, body perception, media, social media

Paper Type: Research

\section{Giriş}

Ergenlik, biyolojik, psikolojik, zihinsel ve sosyal açılardan gelişme, olgunlaşma süreçlerinin yer aldığı çocukluktan yetişkinliğe geçiş dönemidir (Yavuzer, 2014). Ergenlik çağındaki bireyin önemli görevlerinden biri kendi benliğini bulmak ve tanımlamak, diğer bir deyişle özdeşleşmeyi sağlamaktır. Ergen, ergenlik çağında kendi benliğini bulmak için birçok farklı yol dener ve birçok kimliğe bürünür. Ergen için çevre ve kendisinin çevresi tarafından nasıl algılandığı çok önemlidir. Bu sebeplerle bireylerin dış etkenlerden etkilenmeye en açık olduğu dönemlerden birisi ergenlik çağıdır. Ergen bu dönemde beğenilmek, önemli olmak ve önemli hissetmek için çabalar. Çocukluktan yetişkinliğe adım atan ergen, aynı zamanda birey olma duygusunu da yavaş yavaş hissetmeye başlamaktadır. Bu dönemde kendisine sık sık 'ben kimim?' 'nereye aitim?' sorularını sormaktadır. Ergen bu sorulara cevap ararken benlik saygısını araç olarak kullanır. Benlik saygısı, ergenin kendine yönelik olumlu veya olumsuz bakış açıları oluşturmasını sağlayarak kendi benliğine yaklaşım şeklini belirlemektedir. Ergenin benlik saygısıyla yakından ilişkili diğer bir kavram ise beden algısıdır. Beden algısı benlik saygısıyla yakından ilişkilendirilmektedir ve benlik saygısı gibi ergenin kendi bedenine yönelik olumlu ve olumsuz algılar oluşturmasını sağlamaktadır. Artan teknoloji kullanımıyla birlikte ergenlerde beden algısı ve benlik saygısını etkileyen diğer bir faktörün medya olduğu gözlemlenmektedir (Sönmez ve Özgen, 2017). Medyanın en büyük hedef kitlelerinden birisi ergenlerdir (Karaboğa, 2016). Ergen, medyanın ona sunduğu dolaylı ve doğrudan mesajlar doğrultusunda karakterini kazanmakta, benlik saygısı ve beden algısını oluşturmaktadır (Steinberg, 2007).

Beden algısı bireyin beden görünümü hakkındaki algısını açıklayan duygu, düşünce ve ifadelerinin bütününden oluşan öznel bir kavramdır (Güzel, 2016). Beden algısı kavramı kadın ve erkeklerde farklı algılanmaktadır buna rağmen hem kadınlar hem erkekler beden algısını genellikle kilo ile ilişkilendirmektedir (Ata, Vural ve Keskin, 2014; Hamurcu, Öner, Telatar ve Yeşildağ, 2015). Beden algısını etkileyen en önemli faktörlerden birisi medyadır. Bireylerin medyanın sunduğu imajlarla kendi imajını karşılaştırdığında beden imajından memnuniyetinin azaldığı bilinmektedir (Bayköse ve Esin, 2019; Clay, Vignoles ve Dittmar, 2005). Bu sebeplerle beden algısı tıbbi-biyolojik kökenlerden çok göstergesel zemine indirgenmiştir. $\mathrm{Bu}$ durum ise bireylerin sağlıklı beden algısı yapısını bozmaktadır (Öngören, 2015). Beden algısındaki bu değişime bağlı olarak yeme bozukluklarının artması, sağlıksız ve gereksiz diyet uygulamaları, yeterli beslenmeme gibi sorunlar ortaya çıkabilmektedir (Aslan, 2004). Ergenlerde de düşük beden algısının ergeni çeşitli kilo verme yöntemlerine ittiği bilinmektedir (Uskun ve Şabaplı, 2013).

Benlik saygıs1, Rosenberg'e (1965) göre bireyin bir obje olarak kendisine yönelttiği duygu ve düşüncelerin toplamıdır. Yüksek benlik saygısı bireyin kendisine değer vermesi, olduğu gibi kendini kabul etmesi anlamında kullanılmaktadır. Ergenlerin, ilk sosyal temaslarının oluştuğu aile ve çevre koşullarının benlik saygısını etkilediği bilinmektedir. Sevildiğini, değer gördüğünü kabul eden bireyler kendisini de sever ve değer verir. $\mathrm{Bu}$ bağlamda ergenin sahip olduğu ailenin anne-baba tutumları, demografik koşulları, sahip olduğu kardeş sayısı gibi etmenlerin benlik saygısını etkilediğini bulgulayan çalışmalar mevcuttur (Özdemir, 2014; Aktaş, 2011; Özkan, 1994; Yiğit, 2010). Ergenlerde benlik saygısını etkileyen diğer bir faktör ise medyadır. Medyanın günümüzde en güçlü dalı haline gelen sosyal medya ve 
sosyal medyaya bağlı kavramlar (beğenilmeme korkusu, paylaşılmama, sosyal karşılaştırma vb.) benlik saygısının güçlü yordayıcılarıdırlar (Söner ve Yılmaz, 2020; Jan, Soomro, Ahmad, 2017). Aynı zamanda sosyal medyayı sık kullanmanın benlik saygısını düşürdüğünü bulgulayan çalışmalar mevcuttur ( Vogel, Rose, Roberts \& Eckles, 2014). Benlik saygısının bireylerin yaşam doyumunun, öznel iyi oluşunun yordayıcısı olduğu bilinmektedir (Çeçen, 2008; Doğan ve Eryılmaz, 2013).

Ergenin bedeninin de fiziksel ve psikolojik değişiklere alışması uzun ve zor bir süreçtir. Bu sebeple ergenin dış faktörlerden etkilenmeye müsait olduğu düşünülmektedir. Diş faktörlerin ise ilk olarak beden algısı ve benlik saygısını etkileyeceği öngörülmektedir. Yapılan araştırmalara bakıldığında, beden algısının benlik saygısını etkilediği görülmektedir (You, Kim ve Shin, 2017; Gökçe, 2017). Ergenlik döneminde olumlu beden algısı yüksek benlik saygısı oluşmasında etkilidir. Yüksek benlik saygısı ve olumlu beden algısı, ergenin sosyal ilişkilerine yansıyarak kendisini daha iyi ve başarılı hissetmesini sağlamaktadır (Aydın, 2005). Beden imajı ve benlik saygısı arasındaki ilişkiyi yaşın ilerlemesi, vücutta şekil bozuklukları ve kalıcı izler, kemoterapi gerektiren hastalıklar, süreğen ve yoğun ilaç kullanımı gerektiren hastalıklar gibi etmenler de etkilemektedir (Ayaz, 2012; Dayanç, 2017; Dubey ve Sarma, 2016; Pike vd., 2012; Vatansever, 2014).

Tüm bu bilgiler ışı̆̆ında ergenlerde benlik saygısı ve beden algısının birbirini etkilediği görülmektedir. Ergenin doğru kabul ettiği beden imajı kavramının sosyal medya ve televizyon tarafından hatalı olarak şekillendirildiği, özellikle benlik saygısı düşük ergenlerde bu durumun daha fazla etki yaptığı düşünülmektedir. Hatalı beden algısından dolayı ergenlerin sağlıksız diyet uygulamaları gibi doğru olmayan telafi yöntemlerine yöneldiği düşünülmektedir. Bu açıdan ergenlerin öncelikle hatalı beden algılarının düzeltilmesi ve düşük benlik saygısına sahip öğrencilerin benlik saygılarını yükselmesine destek olacak çalışmaların yapılması önem arz etmektedir. Yapılan çalışmada lise öğrencilerinin benlik saygısı ve beden algısı düzeyleri ve bu beden algısı ve benlik saygısı düzeylerine sosyal medya kullanımının, düzenli takip edilen televizyon programlarının ve çeşitli demografik özelliklerin etkisinin olup olmadığı tespit edilmeye çalışılacaktır. Ulaşılacak sonuçların ele alınacak konuya farklı bakış açıları sağlayacağı düşünülmektedir. Özellikle okullarda psikolojik danışmanlar tarafından yapılacak olan yüksek benlik saygısı, kendini kabul, doğru beden algısını oluşturmaya yönelik çalışmalara veri oluşturması umut edilmektedir.

\section{Yöntem}

$\mathrm{Bu}$ araştırmada lise öğrencilerinin benlik saygısı ve beden algısı düzeyleri ile medya ürünlerini kullanım düzeyleri arasındaki ilişkinin düzeyini ve yönünü belirleyebilmek için genel tarama modellerinden ilişkisel tarama modeli kullanılmıştır. İlişkisel tarama modeli iki veya daha fazla değişken arasındaki değişimin varlığını ve/veya derecesini belirlemeyi amaçlayan araştırma modelidir. İlişkisel tarama modeli, var olan bir durumu oluşturan değişkenler arasındaki ilişkiyi saptamamızı sağlayan modeldir (Karasar, 2016). Araştırmanın etiği ile ilgili izinler Afyon Kocatepe Üniversitesi Sosyal ve Beşeri Bilimler Bilimsel Araştırma ve Yayın Etiği Kurulu tarafindan 06.04.2018 tarihinde 2018/25 nolu kararla belirlenmiştir.

\subsection{Evren ve Örneklem}

Bu araştırmanın evrenini Millî Eğitim Bakanlığı Konya ili Akşehir ilçesindeki 20172018 eğitim-öğretim yılında öğrenim gören 5014 lise öğrencisi oluşturmaktadır. Araştırmanın örneklemini ise evrenden kolay örnekleme yoluyla seçilen 385 öğrenci oluşturmaktadır. Araştırmada örneklem büyüklügünü belirlemek adına Büyüköztürk ve arkadaşlarının (2016) hesaplamalarından yararlanılmıştır. Büyüköztürk ve arkadaşları (2016), 6000 kişi için $a=.05$ değeri hata payı olarak alındığında örneklem büyüklüğünün 361 kişi olduğunu belirtmişlerdir. Veri kaybı olma ihtimali düşünülerek toplam 500 öğrenci araştırmaya katılmıştır. Yanlış ve eksik doldurulan formlar çıkartılarak 385 form değerlendirmeye alınmıştır. Araştırmaya katılan 
öğrencilerin 283'ü $(\% 73,5) \mathrm{k1z}, 102$ 'si $(\% 26,5)$ erkektir. Araştırmaya katılan öğrencilerin $\% 24,9$ 'u imam hatip lisesi, \%37,4'ü anadolu lisesi ve \%37,7'si mesleki ve teknik anadolu lisesi öğrencisidir ve öğrencilerin \%32,5'i 1000 TL ve altı algılanan sosyo-ekonomik duruma, \%52,5'i 1000-3000 TL algilanan sosyo-ekonomik duruma, \%11,2'si 3000-5000 TL algilanan sosyo-ekonomik duruma, \%3,9'u 5000 TL ve üstü algilanan sosyo-ekonomik duruma sahip olduklarını belirtmişlerdir. Araştırmaya katılan öğrencilerin \%81,1'i çekirdek aileye, \%18,4’ü geniş aileye mensuptur.

\subsection{Veri Toplama Araçları}

Araştırmanın amacı, lise öğrencilerinin beden imajı, benlik saygısı, medya kullanım düzeyleri ve bunların arasındaki ilişkileri incelemek olduğu için veri toplama araçları da buna uygun olarak seçilmiştir. Öğrencilerin beden imajlarını ölçmek için 'Beden Algııs Ölçeği', benlik saygılarını ölçmek için 'Rosenberg Benlik Saygısı Ölçeği' ve kişisel bilgilerini ve medya kullanım düzeylerini öğrenmek için 'Kişisel Bilgi Formu' kullanılmıştır.

\subsection{Verilerin Analizi}

Ölçeklerin uygulanmasının ardından veriler bilgisayar ortamında uygun analiz teknikleri kullanılarak analiz edilmiştir.

$\mathrm{Bu}$ araştırmada çarpıklık ve basıklık değerleri sonucunda verilerin normal dağıldığ gözlemlenmiştir. $\mathrm{Bu}$ nedenle araştırma analizlerinde parametrik testler kullanılmıştır. Katılımcıların Rosenberg Benlik Saygısı ve Beden Algısı puanlarında cinsiyet, aile türü ve diyet uygulanıp uygulanmamasına bağlı anlamlı farklılık olup olmadığını belirlemek için $T$ testi kullanılmıştır. Okul türü, şahsi olarak sahip olunan teknolojik alet sayısı, sosyal medya platformlarında sahip olunan şahsi profil sayısı, günlük tablet/telefon kullanım süresi, haftalık düzenli takip edilen dizi sayısı, televizyonda en çok izlenen program türü ve vücuda estetik amaçlı müdahalede bulunup bulunmadığının açısından anlamlı bir farklılık olup olmadığı bulgulamak için Anova testi kullanılmıştır.

\section{Bulgular ve Tartışma}

Bu bölümde araştırmanın alt problemlerine dair bulgulara ve yorumlara yer verilmiştir.

\section{1. Öğrencilerin Benlik Saygısı ve Beden Algısı Düzeyleri Arasındaki İliş̧kiye Dair Bulgular}

Çalışmada öğrencilerin benlik saygısı ve beden algısı düzeyleri arasındaki ilişkiyi incelemek için Pearson korelasyon testi uygulanmıştır.

Tablo 1. Rosenberg benlik saygısı ve beden algısı ölçeğinden alınan puanların arasındaki ilişkiyi gösteren pearson korelasyon testi

\begin{tabular}{lll}
\hline Pearson & 1 & 2 \\
\hline Benlik Saygis1 & 1 &,- 465 \\
\hline$\overline{\mathrm{x}}$ & 1,7065 & 144,3299 \\
\hline ss &, 69939 & 35,50987 \\
\hline
\end{tabular}

Tablo 1'e göre öğrencilerin benlik saygıları ile beden algısı düzeyleri arasında orta düzeyde negatif ve anlamlı bir ilişki olduğu $(r=-, 465 \mathrm{p}=, 0)$ gözlemlenmektedir. Benlik saygısı ölçeğinden alınan puanlar arttıkça beden algısı puanları düşmektedir. Benlik saygısı ölçeğinde düşük puan yüksek benlik saygısını göstermektedir. Beden algısı ölçeğinden alınan puanların artması olumlu beden algısı olduğunu işaret etmektedir. Öğrencilerin benlik saygılarının artması olumlu beden algılarının artması arasında orta düzeyde anlamlı bir ilişki vardır. 


\section{2. Öğrencilerin Cinsiyetlerine Göre Benlik Saygısı ve Beden Algısı Düzeylerine Dair Bulgular}

Öğrencilerin cinsiyetlerine göre benlik saygısı ve beden alg1sı düzeyleri arasında anlamlı bir farklılığın olup olmadığını belirlemek için T testi yapılmıştır.

Tablo 2. Rosenberg benlik saygısı ve beden algısı ölçeğinden alınan puanların cinsiyete göre

$$
\text { farkl1lı̆̆ını gösteren t testi }
$$

\begin{tabular}{llllllll} 
& Cinsiyet & $\mathrm{n}$ & $\overline{\mathrm{x}}$ & $\mathrm{S}$ & $\mathrm{sd}$ & $\mathrm{t}$ & $\mathrm{p}$ \\
\hline Benlik Sayg1s1 & K1z & 283 & 199,03 &, 68 & 383 & 1,33 & \multirow{2}{*}{, 183} \\
\cline { 2 - 7 } & Erkek & 102 & 176,26 &, 73 & & & \\
\hline Beden Alg1S1 & Kiz & 283 & 181,70 & 36,51 & 383 & $-3,292$ & \multirow{2}{*}{001} \\
\cline { 2 - 6 } & Erkek & 102 & 224,34 & 30,64 & &
\end{tabular}

Tablo 2'ye bakıldığında kız ve erkek öğrencilerin benlik saygısı ölçeğinden aldıkları puanlar arasında anlamlı bir farklılık $(\mathrm{p}=, 183)$ bulunmamıştır. Buna karşıllı kız ve erkek ögrencilerin beden algısı ölçeğinden aldıkları puanlar arasında anlamlı bir farklılık $(p=, 001)$ vardır. Kız öğrencilerin beden algısı ölçeğinden aldıkları puanların sıra ortalamaları 181,70 iken erkek öğrencilerin 224,34'tür. Bu veriler ışığında erkek öğrencilerin daha olumlu beden algısına sahip olduğu söylenebilir.

\section{3. Öğrencilerin Okuduklari Okul Türüne Göre Benlik Saygısı ve Beden Algısı Düzeylerine Dair Bulgular}

Öğrencilerin okudukları okul türüne göre benlik saygısı ve beden algısı düzeyleri arasında anlamlı bir farklılık gösterip göstermediğini belirlemek amacıyla varyans analizi yapılmıştır.

Tablo 3. Rosenberg benlik saygısı ve beden algısı ölçeğinden alınan puanların okul türüne göre

\begin{tabular}{|c|c|c|c|c|c|c|}
\hline \multicolumn{7}{|c|}{ kl1lığını gösteren anova testi } \\
\hline & Varyansın kaynağı & $\begin{array}{l}\text { Kareler } \\
\text { top. }\end{array}$ & $\mathrm{sd}$ & $\begin{array}{l}\text { Kareler } \\
\text { ortalamas1 }\end{array}$ & $\mathrm{F}$ & $\mathrm{p}$ \\
\hline \multirow{3}{*}{$\begin{array}{l}\text { Benlik } \\
\text { Saygis1 }\end{array}$} & Gruplar arası & ,39 & 2 & ,195 & \multirow[t]{3}{*}{,39 } & \multirow[t]{3}{*}{,672 } \\
\hline & Gruplar içi & 187,44 & 382 & ,491 & & \\
\hline & Toplam & 187,83 & 384 & & & \\
\hline \multirow{3}{*}{$\begin{array}{l}\text { Beden } \\
\text { Algis1 }\end{array}$} & Gruplar aras1 & 4389,72 & 2 & 2194,86 & \multirow[t]{3}{*}{2,77} & \multirow[t]{3}{*}{, 176} \\
\hline & Gruplar içi & 479815,37 & 382 & 1256,06 & & \\
\hline & Toplam & 484205,10 & 193,63849 & & & \\
\hline
\end{tabular}

Tablo 3'e baktığımızda öğrencilerin okul türüne göre benlik saygısı ve beden algıs1 ölçeklerinden aldıkları puanlar anlamlı bir farklılık $(p=, 672, p=, 176)$ göstermemektedir.

\section{4. Öğrencilerin Aile Türüne Göre Benlik Saygısı ve Beden Algısı Düzeylerine Dair Bulgular}

Öğrencilerin aile türüne göre benlik saygısı ve beden algısı düzeyleri arasında anlamlı bir farklılığın var olup olmadığını anlamak için t testi uygulanmıştır. 
Tablo 4. Rosenberg benlik saygısı ve beden algısı ölçeğinden alınan puanların aile türüne göre farklılığını gösteren t testi

\begin{tabular}{llllllll} 
& Cinsiyet & $\mathrm{n}$ & $\overline{\mathrm{x}}$ & $\mathrm{S}$ & $\mathrm{sd}$ & $\mathrm{t}$ & $\mathrm{p}$ \\
\hline \multirow{2}{*}{ Benlik Saygıs1 } & Çekirdek aile & 314 & 1,6783 &, 69 & \multirow{2}{*}{383} & $-1,665$ & \multirow{2}{*}{097} \\
& Geniş Aile & 71 & 1,8310 &, 69 & & & \\
\hline \multirow{2}{*}{ Beden Algıs1 } & Çekirdek aile & 314 & 144,2834 & 35,59 & 383 &,- 054 & \multirow{2}{*}{, 957} \\
\cline { 2 - 5 } & Geniş Aile & 71 & 144,5352 & 35,38 & & & \\
\hline
\end{tabular}

Tablo 4'e baktığımızda öğrencilerin aile türüne göre benlik saygısı ve beden algısı düzeyleri arasında anlamlı bir farklılık $(\mathrm{p}=, 097 \mathrm{p}=, 957)$ bulunamamıştır.

\section{5. Öğrencilerin Algılanan Sosyo-Ekonomik Durumuna Göre Benlik Saygısı ve Beden Algısı Düzeylerine Dair Bulgular}

Öğrencilerin algıladıkları sosyo-ekonomik duruma göre benlik saygısı ve beden algısı düzeyleri arasında anlamlı bir farklılık gösterip göstermediğini belirlemek amacıyla varyans analizi yapılmıştır.

Tablo 5. Rosenberg benlik saygısı ve beden algısı ölçeğinden alınan puanların algılanan sosyoekonomik duruma göre farklılı̆̆ını gösteren anova testi

\begin{tabular}{rllllll} 
& Varyansın & Kareler top. & sd & Kareler ortalamas1 & F & p \\
\hline Benlik & Gruplar aras1 & 2,681 & 3 &, 894 & 1,839 & \multirow{2}{*}{140} \\
\cline { 2 - 5 } Saygıs1 1 & Gruplar içi & 185,152 & 381 &, 486 & & \\
\cline { 2 - 5 } & Toplam & 187,834 & 384 & & \multirow{2}{*}{1,093} & \multirow{2}{*}{, 352} \\
\hline Beden & Gruplar aras1 & 4129,882 & 3 & 1376,627 & & \\
\cline { 2 - 5 } Alg1s1 & Gruplar içi & 480075,225 & 381 & 1260,040 & & \\
\cline { 2 - 4 } & Toplam & 484205,106 & 384 & & & \\
\hline
\end{tabular}

Öğrencilerin algıladıkları sosyo-ekonomik duruma göre benlik saygısı ve beden algıs1 düzeyleri arasında anlamlı $(\mathrm{p}=, 140, \mathrm{p}=, 352)$ bir farklılık bulunamamıştır.

\section{6. Öğrencilerin Kullandığı Şahsi Sosyal Medya Profil Sayılarına Göre Benlik Saygısı ve Beden Algısı Düzeylerine Dair Bulgular}

Öğrencilerin kullandığı şahsi sosyal medya hesaplarına göre benlik saygısı ve beden algısı düzeyleri arasında anlamlı bir farklılık olup olmadığını belirlemek amacıyla varyans analizi yapılmıştır.

Tablo 6. Rosenberg benlik saygısı ve beden algısı ölçeğinden alınan puanların sosyal medya profil sayısına göre farklılığını gösteren anova testi

\begin{tabular}{|c|c|c|c|c|c|c|}
\hline & Varyansin & Kareler top. & $\mathrm{sd}$ & Kareler & $\mathrm{F}$ & $\mathrm{p}$ \\
\hline \multirow{3}{*}{$\begin{array}{r}\text { Benlik } \\
\text { Saygis1 }\end{array}$} & Gruplar aras1 & 3,529 & 9 & ,392 & \multirow[t]{3}{*}{,798 } & \multirow[t]{3}{*}{,619 } \\
\hline & Gruplar içi & 184,305 & 375 & ,491 & & \\
\hline & Toplam & 187,834 & 384 & & & \\
\hline \multirow{3}{*}{$\begin{array}{l}\text { Beden } \\
\text { Algis1 }\end{array}$} & Gruplar arası & 1134035,5 & 9 & 1259,504 & \multirow[t]{3}{*}{,999 } & \multirow[t]{3}{*}{,440 } \\
\hline & Gruplar içi & 472869,566 & 375 & 1260,986 & & \\
\hline & Toplam & 484205,106 & 384 & & & \\
\hline
\end{tabular}

Tablo 6'ya göre öğrencilerin kullandığı şahsi sosyal medya hesaplarına göre benlik saygısı ve beden algısı düzeyleri arasında anlamlı bir farklılık $(p=, 619 p=, 440)$ bulunamamıştır. 


\section{7. Öğrencilerin Günlük Tablet|Telefon Kullanım Süresine Göre Benlik Saygısı ve Beden Algısı Düzeylerine Dair Bulgular}

Öğrencilerin günlük tabletltelefon kullanım süresine göre benlik saygısı ve beden algısı düzeyleri arasında anlamlı bir farklılık olup olmadığını belirlemek adına varyans analizi yapılmıştır.

Tablo 7. Rosenberg benlik saygısı ve beden algısı ölçeğinden alınan puanların günlük tablet/telefon kullanım süresine göre farklı1ığını gösteren ANOVA testi

\begin{tabular}{rllllll} 
& Varyansın & Kareler top. & sd & Kareler & F & p \\
\hline Benlik & Gruplar aras1 & 5,259 & 4 & 1,315 & 2,736 & \multirow{2}{*}{290} \\
\cline { 2 - 5 } Saygis1 & Gruplar içi & 182,575 & 380 &, 480 & & \\
\cline { 2 - 5 } & Toplam & 187,834 & 384 & & \multirow{2}{*}{1,109} & \multirow{2}{*}{, 352} \\
\hline Beden & Gruplar aras1 & 5587,170 & 4 & 1396,793 & \\
\cline { 2 - 5 } Alg1s1 & Gruplar içi & 478617,936 & 380 & 1259,521 & & \\
\cline { 2 - 4 } & Toplam & 484205,106 & 384 & & & \\
\hline
\end{tabular}

Tablo 7'ye göre öğrencilerin günlük tabletltelefon kullanım süresine göre benlik saygıs1 ve beden algısı düzeyleri arasında anlamlı bir farklılık $(p=, 290, p=, 352)$ tespit edilememiştir.

\section{8. Öğrencilerin Düzenli Takip Ettiği Televizyon Programları Sayısına Göre Benlik Saygısı ve Beden Algısı Düzeylerine Dair Bulgular}

Öğrencilerin düzenli takip ettiği televizyon programları sayısına göre benlik saygısı ve beden algısı düzeyleri arasında anlamlı bir farklılığın var olup olmadığını tespit etmek amacıyla varyans analizi yapılmıştır.

Tablo 8. Rosenberg benlik saygısı ve beden algısı ölçeğinden alınan puanların düzenli takip edilen televizyon programı sayısına göre farklılığını gösteren anova testi

\begin{tabular}{rllllll} 
& Varyansın & Kareler top. & sd & Kareler & F & p \\
\hline Benlik & Gruplar aras1 &, 947 & 4 &, 237 & \multirow{2}{*}{, 481} & \multirow{2}{*}{,750 } \\
\cline { 2 - 5 } Saygis1 & Gruplar içi & 186,887 & 380 &, 492 & & \\
\cline { 2 - 5 } & Toplam & 187,834 & 384 & & \multirow{2}{*}{, 106} & \multirow{2}{*}{, 980} \\
\hline Beden & Gruplar aras1 & 539,976 & 4 & 134,994 & & \\
\cline { 2 - 5 } Alg1s1 & Gruplar içi & 483665,130 & 380 & 1272,803 & & \\
\cline { 2 - 4 } & Toplam & 484205,106 & 384 & & & \\
\hline
\end{tabular}

Tablo 8'e bakıldığında öğrencilerin düzenli takip ettiği televizyon programları sayısına göre benlik saygısı ve beden algısı düzeyleri arasında anlamlı bir farklılık $(p=, 750 p=, 980)$ bulunamamıștır.

\section{9. Öğrencilerin En Çok İzlediği Televizyon Program Türlerine Göre Benlik Saygısı ve Beden Algısı Düzeylerine Dair Bulgular}

Öğrencilerin en çok izlediği televizyon program türlerine göre benlik saygısı ve beden algısı düzeyleri arasında anlamlı bir farklılığın var olup olmadığını tespit etmek amacıyla varyans analizi yapılmıştır.

Tablo 9. Rosenberg benlik saygısı ve beden algısı ölçeğinden alınan puanların en çok izlediği televizyon program türleri göre farklılığını gösteren anova testi

\begin{tabular}{|c|c|c|c|c|c|c|}
\hline & Varyansin & Kareler top & $\mathrm{sd}$ & Kareler & $\mathrm{F}$ & $\mathrm{p}$ \\
\hline \multirow{3}{*}{$\begin{array}{r}\text { Benlik } \\
\text { Saygis1 }\end{array}$} & Gruplar aras1 & 3,482 & 5 & ,696 & \multirow[t]{3}{*}{1,432} & \multirow[t]{3}{*}{,212 } \\
\hline & Gruplar içi & 184,352 & 379 & ,486 & & \\
\hline & Toplam & 187,834 & 384 & & & \\
\hline Beden & Gruplar aras1 & 9397,439 & 5 & 1879,488 & 1,500 & , 189 \\
\hline
\end{tabular}




\begin{tabular}{lllll} 
Alg1s1 & Gruplar içi & 474807,667 & 379 & 1252,791 \\
\cline { 2 - 5 } & Toplam & 484205,106 & 384 &
\end{tabular}

Tablo 9'a göre öğrencilerin en çok izlediği televizyon program türlerine göre benlik saygısı ve beden algısı düzeyleri arasında anlamlı bir farklılık $(p=, 212, p=, 189)$ bulunamamıştır.

\subsection{0. Öğrencilerin Diyet Uygulama Durumuna Göre Benlik Saygısı ve Beden Algısı Düzeylerine Dair Bulgular}

Öğrencilerin diyet uygulama durumuna göre benlik saygısı ve beden algısı düzeyleri arasında anlamlı bir farklılığın olup olmadığını belirlemek için T testi yapılmıştır.

Tablo 10. Rosenberg benlik saygısı ve beden algısı ölçeğinden alınan puanların diyet uygulama durumuna göre farklıllı̆ını gösteren $\mathrm{t}$ testi

\begin{tabular}{|c|c|c|c|c|c|c|c|}
\hline & Diyet uygulama durumu & $\mathrm{n}$ & $\overline{\mathrm{x}}$ & S & sd & $\mathrm{t}$ & $\mathrm{p}$ \\
\hline \multirow{2}{*}{$\begin{array}{l}\text { Benlik } \\
\text { Saygis1 }\end{array}$} & Diyet Uygularım & 140 & 1,9143 & 67 & \multirow[t]{2}{*}{383} & \multirow[t]{2}{*}{4,517} & \multirow[t]{2}{*}{001} \\
\hline & Diyet Uygulamam & 245 & 1,5878 & ,68 & & & \\
\hline \multirow{2}{*}{$\begin{array}{l}\text { Beden } \\
\text { Algis1 }\end{array}$} & Diyet Uygularım & 140 & 138,45 & 39,20 & \multirow[t]{2}{*}{383} & \multirow[t]{2}{*}{$-2,472$} & \multirow[t]{2}{*}{,013 } \\
\hline & Diyet Uygulamam & 245 & 147,68 & 32,82 & & & \\
\hline
\end{tabular}

Tablo 10'a göre öğrencilerin diyet uygulama durumuna göre benlik saygısı ve beden algısı düzeyleri arasında anlamlı bir farklıl1k $(\mathrm{p}=, 0 \mathrm{p}=, 013)$ bulunmuştur. Verilere göre diyet uygulayan öğrencilerin 1,9143 puan ortalaması ile en yüksek benlik saygısı puanlarına sahip iken, en yüksek beden algısı puanlarına 138,45 ortalama sira puanları diyet uygulamayan öğrenciler sahiptir. Diyet uygulayan öğrencilerin benlik saygısı daha düşük ve beden algıları daha olumsuz olarak bulgulanmıştır.

\section{Sonuç ve Öneriler}

Çalışmanın bu bölümünde öğrencilerin benlik saygısı ve beden algısı düzeyleri arasında anlamlı bir farklılığın olup olmadığ 1 ve çeşitli değişkenler açısından farklılaşıp farklılaşmadığ alanyazın çerçevesinde tartışılmış ve yorumlanmıştır. Bulgulara göre öğrencilerin cinsiyet, okul türü, diyet uygulama durumu ile beden algısı öleceği puanları arasında düşük düzeyde pozitif yönde anlamlı bir farklılık vardır. Öğrencilerin algılanan sosyo-ekonomik durum ve diyet uygulama durumu ile benlik saygısı ölçeği puanları arasında düşük düzeyde negatif yönlü, günlük tablet/telefon kullanım süresi ile düşük düzeyde pozitif yönlü anlamlı farklılık vardır. Araştırma bulgularına göre öğrencilerin \%43,4'ü yüksek düzey benlik saygısına, \%42,6'sı orta düzey benlik saygısına ve \%14'ü düşük düzey benlik saygısına sahiptir. Öğrencilerin \%83,6'sı genel olarak kendilerinden memnun olduklarını belirtmişlerdir. Bu veriler 1şı̆̆ında öğrencilerin genel olarak yüksek benlik saygısına sahip oldukları söylenebilir.

Öğrencilerin benlik saygısı ve beden algısı düzeyleri arasında orta düzeyde negatif yönde ve anlamlı bir ilişki olduğu gözlemlenmektedir. Öğrencilerin benlik saygısından aldığı puanlar arttıkça beden algısı ölçeğinden aldığı puanlar azalmaktadır. Benlik saygısı ölçeğinden alınan puanlar yükseldikçe düşük benlik saygısı artmaktadır. Alınabilecek en yüksek puan olan 6 puan, en düşük benlik saygısını yordamaktadır. Beden algısı ölçeğinde ise alınan puanların artması, olumlu beden algısının arttığını göstermektedir. Bu bilgiler 1şığında öğrencilerin benlik saygıları arttıkça olumlu beden algılarının da arttığı saptanmıştır. Gatti ve arkadaşları (2014) üzerinde yaptığ 1 çalışmada da ergenlerde beden algısı ve benlik saygısı arasında anlamlı bir farklılığın olduğu tespit edilmiş̧ir. Ergenlerde negatif beden algısı benlik saygını olumsuz biçimde etkilemektedir. Oktan ve Şahin (2010) yaptığı araştırmalarında beden algısı ile benlik 
saygısı arasında pozitif yönde anlamlı ilişki saptamıştır. Benlik saygısı arttıkça beden doyumu da artmaktadır. Bu bulgular araştırmamızın bulgularını destekler niteliktedir.

Araştırmaya katılan öğrencilerin \%73,5'i kız, \%26,5'i erkektir. Erkek öğrencilerin benlik saygısı düzeyleri kız öğrencilere göre daha yüksektir. Yapılan diğer çalışmalarda bu bulguyu desteklemektedir (Aygör, 2010; Moksnes ve Espnes, 2013). Cinsiyet ile beden algis1 ölçeği arasında anlamlı bir ilişki saptanmıştır. Ancak araştırmada cinsiyete göre benlik saygısı ve beden algısı arasında anlamlı bir farklılık bulunamamıştır.

Öğrencilerin okul türü ile beden algısı ölçeği puanları arasında düşük düzeyde bir ilişki saptanmıştır. Ancak öğrencilerin okul türüne göre benlik saygısı ve beden algısı ölçeklerinden aldıkları puanlar anlamlı bir farklılık göstermemektedir. Dilek ve Aksoy (2013) lise öğrencileri ile yaptığ araştırmada meslek, düz ve anadolu türünde liselerin benlik saygısına etkisini araştırmıştır. Araştırma bulgularına göre okul türlerine göre benlik saygısı arasında ilişki saptanmamıştır. Aksüt (2011) lise düzeyi okullarda yaptığ1 çalışmada okul türlerinin benlik saygısına etkisini araştırmıştır. Araştırma bulgularına göre okul türü ile benlik saygısı düzeyleri arasında anlamlı bir ilişki bulunamamıştır. $\mathrm{Bu}$ bulgular yapılan araştırmayı destekler niteliktedir.

Öğrencilerin algılanan sosyo-ekonomik durumuna göre benlik sayg1sı düzeyleri arasında düşük seviyede ilişki bulunmuştur ancak öğrencilerin algıladıkları sosyo-ekonomik duruma göre benlik saygısı ve beden algısı düzeyleri arasında anlamlı bir farklılık göstermemektedir. Benlik saygısı ölçeğinden alınan puanların ortalamasına bakıldığında algılanan sosyo-ekonomik durumu 1000 TL ve altı olan öğrenciler en düşük benlik saygısına, 3000-5000 TL algılanan sosyo-ekonomik duruma dahil öğrenciler en yüksek benlik saygısına sahip olan gruptur. Öğrencilerin beden algısı ölçeğinden aldıkları puanların sosyo-ekonomik duruma göre dağılımına baktığımızda 1000 TL ve altı algılanan sosyal duruma sahip öğrenciler olumlu beden algisı en düşük öğrenciler iken olumlu beden algisı en yüksek olan grup $5000 \mathrm{TL}$ ve üstü algılanan sosyo-ekonomik duruma sahip olan öğrencilerdir. Uğurlu ve Akın (2008) yaptıkları çalışmada sosyo-ekonomik durumun beden algısını etkilediğini tespit etmişlerdir. Sosyo-ekonomik konum yükseldikçe olumlu beden algısının arttığını saptamışlardır. Bu sonuçlar yapılan çalışma ile uyum göstermektedir.

Öğrencilerin kullandığ şahsi sosyal medya hesap sayısına göre, günlük tabletltelefon kullanım süresine göre, düzenli takip ettiği televizyon programları sayısına göre, en çok izlediği televizyon programı türlerine göre, benlik saygısı ve beden algısı düzeyleri arasında anlamlı bir farklılık bulunamamıştır. Hawi ve Samaha'nın (2017) yaptığı araştırmada sosyal medyanın bağımlılık yapıcı kullanımının benlik saygısını etkilediği tespit edilmiştir. Bu bulgu bizim araştırmamızla örtüşmemektedir. Sosyal medya araçları en fazla mobil uygulamalardan kullanılmaktadır. Sabırlı'nın da (2018) araştırmasında benlik saygısı ve akıllı telefon bağımlılığ arasında anlamlı bir farklı1ık bulunamamıştır. Bu bulgu çalışmamızı destekler niteliktedir.

Öğrencilerin diyet uygulama oranına göre benlik saygısı ve beden algısı düzeyleri arasında anlamlı bir farklılık bulunmuş̧tur. Analizler sonucunda diyet uygulayan öğrencilerin benlik saygısı düzeylerinin, uygulamayanlara oranla daha düşük olduğu tespit edilmiştir. Ercan (2018) yaptığı araştırmada geç ergenlikte sosyal medya maruziyeti ile sosyal görünüş kaygıs1 arasında anlamlı bir ilişki saptamıştır. Aynı zamanda geç ergenlikte sosyal görünüş kaygısı ile beden algısı arasında anlamlı bir iliş̧ki saptanmıştır. Örsel ve arkadaşları (2004) yaptığı araştırmada 15-17 yaş arasındaki 531 lise öğrencisi ile diyet yapma durumunun benlik saygısı ve beden algısına etkisini araştırmıştır. Çalışma bulgularına göre, kız öğrencilerin \%33'ü normal beden kitle endeksine sahip olmasına rağmen diyet yapmaktadır. Diyet uygulama durumu ile beden algısı ve benlik saygısı arasında anlamlı bir ilişki bulunmuştur. Diyet yapan gruplarda beden algısı ve benlik saygısı daha düşük olarak saptanmıştır. Ergen üzerinde yapılan başka bir araştırmada ağırlıkları normalden fazla olan ergenlerin daha düşük benlik saygına sahip olduğu bulgulanmıştır (Işıklar, 2012). Çalışmalara bakıldığında olduğu kiloyu beğenmemek, normal 
üstü kiloya sahip olmak, diyet uygulamak genel olarak dış görünüşten memnun olmamak olarak isimlendirebilir. Dış görünüş ise beden algısı ile ilgili bir kavramdır. Araştırmamızda diyet uygulama durumunun benlik saygısı ve beden algısını olumsuz etkilediği saptanmıştır. $\mathrm{Bu}$ bağlamda araştırma sonuçlarımız yapılmış diğer araştırma sonuçlarına uygun olmaktadır.

Yaptığımız araştırma konusunda Türkiye'de başka araştırmaya rastlanılmamıştır. Türkiye'deki araştırmalar medya ve yeme bozukluğu, yeme bozukluğu ve benlik saygısı, yeme bozukluğu ve beden algısı gibi alanlarda yoğunlaşmaktadır. Bu alanlar araştırmamıza yakın olmakla birlikte tam olarak örtüşmemektedir. Bu sebeple araştırma sonuçları için kesin bir karşılaştırma yapılamamaktadır.

Algılanan sosyo-ekonomik durum, sahip olunan teknolojik alet sayısı ile benlik saygis1 arasında anlamlı farklılığa rastlanmıştır. Öğrencilerin sosyo-ekonomik durumları arttıkça benlik saygısı düzeyleri artmaktadır. Günlük tablet/telefon kullanım süresi ile benlik saygısını arasında anlamlı farklılık bulgulanmıştır. Ancak günlük tablet/telefon kullanım süresi arttıkça benlik saygisı azaltmaktadır. Diyet uygulama durumu hem benlik saygisı hem de beden algısı arasında anlamlı bir ilişki saptanmıştır. Araştırma bulgularına göre diyet uygulamayan öğrencilerin benlik saygıları daha yüksek, beden algıları daha olumludur.

Araştırmamızda diyet uygulama durumunun benlik saygısı ve beden algısını etkilediği saptanmıştır. Ergenlik döneminde ergen dış görünüşüne çok önem vermektedir. $\mathrm{Bu}$ durum ergenleri kabul gören güzellik ölçülerine ulaşmak için doğru olmayan inançlara ve sağlıksız yöntemlere itebilir. Bu sebeple dış görünüş ile benlik saygısı ve beden algısı arasındaki ilişki daha kapsamlı incelenebilir. Ayrıca ergenlerin diyet ve estetik müdahaleler ile ilgili uzmanlardan yardım almasının, yol gösterilmesinin ergen beden ve ruh sağlığı için katk1 sağlayacağ 1 düşünülmektedir.

Araştırma bulgularında kızların daha fazla olumsuz beden algısına sahip oldukları görülmektedir. Alanda benzer sonuçların alındığı çalışmalar mevcuttur. Bu bulgu daha derin araştırabilir. Araştırmada günlük tablet-telefon kullanımı, düzenli takip edilen program sayısı ve türü araştırmacının kendisi tarafından hazırlanan form yoluyla elde edilmiştir bu durum araştırma verilerini sınırlamaktadır. Benzer bilgiler geçerlilik ve güvenirlik çalışmaları yapılmış ölçme araçlarıyla toplandığında daha ayrıntılı bilgiler elde etmek adına araştırmacılara önerilmektedir. Araştırmamızda medya değişkeni çok genel kalmıştır, daha özele indirgenen bir araştırma daha kapsamlı sonuçlar verebilir. Örneğin sosyal medyanın benlik saygısı ve beden algısına etkisi gibi. Bu çalışmada kişisel veri formundan elde edilen bilgiler, geçerliliği ve güvenirliği yapılmış ölçekler tarafından elde edilebilir. Araştırmada daha net sonuçlar almak için sosyal görünüş kaygısı ölçeği, internet bağımlılığı ölçeği, akıllı telefon bağımlılığ 1 ölçeği, sosyal medya bozukluğu ölçeği gibi farklı ölçeklerle araştırma tekrar yapılabilir.

\section{Kaynakça}

Aksüt, A. (2011). The relatıonship between students' self-esteem, parental attitudesand students' achlevement in foreıgn language learnıng. (Yayınlanmamış yüksek lisans tezi). Trakya Üniversitesi, Edirne.

Aslan, D. (2004). Beden algısı ile ilgili sorunların yaratabileceği beslenme sorunları. Sürekli Tıp Eğitimi Dergisi, 13(9),326-329.

Ata, A., Vural, A., Keskin, F. (2014). Beden algis1 ve obezite. Ankara Medical Journal, 14(3), 74-84.

Ayaz, A. (2012). Meme kanserli kadınlarda beden imajı ve benlik saygısı. (Yayınlanmamış Yüksek lisans tezi). Haliç Üniversitesi, İstanbul.

Aydın, B. (2005). Çocuk ve ergen psikolojisi. (2. Basım). İstanbul: Atlas Yayın Dağıtım. 
Aygör, N. (2010). 12-14 yaş grubu ergenlerde beden bölgelerinden ve özelliklerinden hoşnut olma durumu ve beden imajının değerlendirilmesi. (Yayınlanmamış yüksek lisans tezi). Haliç Üniversitesi Sağlık Bilimleri Enstitüsü, İstanbul.

Büyüköztürk Ş, Çakmak, E. Akgün, Ö. Karadeniz, Ş. Demirel, F. (2016). Bilimsel araştırma yöntemleri. (21. Bask1). Ankara: Pegem Akademi.

Canpolat, B. I., Örsel, S., Akdemir, A. Özbay, M. H. (2003). Ergenlerin kendilik algısında beden imajının ve beden kitle indeksinin rolü. 3P Dergisi, 11(2): 143154.

Clay, D., Vignoles, V. L., Dittmar, H. (2005). Body image and self-esteem among adolescent girls: Testing the influence of sociocultural factors. Journal of Research on Adolescence, 15(4), 451-477.

Çeçen, A.R. (2008). Üniversite öğrencilerinde yaşam doyumunu yordamada bireysel bütünlük (tutarlılık) duygusu, aile bütünlük duygusu ve benlik saygısı. Eğitimde Kuram ve Uygulama,4(1),19-30.

Dayanç, İ. (2017). Kemoterapiye bağlı alopesi gelişen hastaların beden imajı ve benlik saygısının belirlenmesi. (Yayınlanmamış yüksek lisans tezi). İstanbul Medipol Üniversitesi, İstanbul.

Dilek, H., Aksoy, A. (2013). Ergenlerin benlik saygısı ile anne-babalarının benlik saygıs1 arasındaki ilişkinin incelenmesi. Ahi Evran Üniversitesi Kırşehir Eğitim Fakültesi Dergisi,14 (3), 95-109.

Doğan, T., Eryılmaz, A. (2013). Benlik saygısı ve öznel iyi oluş arasındaki ilişkilerin incelenmesi. Pamukkale Üniversitesi Eğitim Fakültesi Dergisi, 33(33), 107-117.

Dubey, M. Sharma, O. (2016). Body image, self-esteemand psychological well-being of aged: a correlational study, Indian Associationof Health, Research and Welfare, ISSN-P-2229-5356, e-2321-3698

Ercan, M. (2018). Geç Ergenlik döneminde sosyal medya maruziyetinin beden algısı ile ilişkisi. (Yayınlanmamış Yüksek lisans tezi). Üsküdar Üniversitesi, İstanbul.

Gatti, E., Ionio, C., Traficante, D., Confalonieri, E. (2014). "I Like my body; therefore, 1 like myself": how body image influences self-esteem - a cross-sectional study on 1talian adolescents. Europe's Journal of Psychology, 10(2), 301-317. https://doi.org/10.5964/ejop.v10i2.703

Gökçe, G. (2017). Lise Öğrencilerinde benlik saygısı ve beden algısı arasındaki ilişkinin incelenmesi. (Yayınlanmamış yüksek lisans tezi). Haliç Üniversitesi, İstanbul.

Güzel, K. (2016). Üniversite ögrencilerinin beden algısının depresyon ile ilişkisi: Mizacın Rolü. (Yayınlanmamış Yüksek Lisans Tezi). Üsküdar Üniversitesi, İstanbul.

Hamurcu, P., Öner, C., Telatar, B., Yeşildağ, Ş. (2015). Obezitenin benlik saygısı ve beden algıs1 üzerine etkisi. Türk Aile Hekimliği Dergisi,19(3), 122-129. doi: 10.15511/tahd.15.02122

Hawi, N. S., Samaha, M. (2017). The relations among social media addiction, self-esteem, and life satisfaction in university students. Social Science Computer Review, 35(5), 576586. https://doi.org/10.1177/0894439316660340

Jan, M., Soomro,S., Ahmad, N. (2017). Impact of social media on self-esteem. European Scientific Journal, 13(23), 329-341.

Işıklar, A. (2012). Ergenlerde yaşam kalitesi ve benlik saygısı düzeyinin cinsiyet ve obezite değiş̧kenleri açısından incelenmesi. Fırat Üniversitesi Sosyal Bilimler Dergisi, 22 (2), 84-92. 
Karaboğa, T. (2016). Medya sosyolojisi bağlamında televizyon dizilerinde tüketim olgusu ve dizilerin bireylerin tüketim eğilimleri üzerinde etkisi. (Yayınlanmamış doktora tezi). Mersin Üniversitesi, Mersin.

Karasar, N. (2016). Bilimsel araştırma yöntemi. Ankara: Nobel Yayınları.

Moksnes, U., Espnes,G. (2013). Self-esteem and life satisfaction in adolescents-gender and age as potential moderators. Quality of Life Research , 22, 2921-2928.

Oktan, V., Şahin, M. (2010). Kız ergenlerde beden imajı ile benlik saygısı arasındaki ilişkinin incelenmesi. Uluslararası Insan Bilimleri Dergisi, 7(2), 543-556.

Öngören, B. (2015). Sosyolojik açıdan sağlıklı beden imgesi. Sosyal ve Beşeri Bilimler Araştırmaları Dergisi, 16 (34), 25-45.

Örsel S., Canpolat BN., Akdemir A. (2004). Diyet yapan ve yapmayan ergenlerin kendilik algısı, beden imajı ve beden kitle indeksi açısından karşılaştırılması. Türk Psikiyatri Dergisi, $15(1), 5-15$.

Özdemir, Y. (2014). Parent-Adolescent Conflict and Depression Symptoms of Adolescents: Mediator Role of Self-Esteem. Dusunen Adam: Journal of Psychiatry \& Neurological Sciences.27(3), 211-220.

Özkan, İ. (1994). Benlik saygısını etkileyen etkenler. Düşünen Adam,7(3).

Pike, N. Evangelista L., Doering, L., Eastwood, J., Lewis, A., Child, J. (2012). Sex and age differences in body-1mage, self-esteem, and body mass index in adolescents and adults after single-ventricle palliation. Pediatr Cardiol, 33, 705-712. 0198-7

Sabırlı, B. (2018). Üniversite öğrencilerindeki akıllı telefon kullanım sılkl̆ğııı benlik saygısı ve çeşitli değişkenlerle iliş̧kisi. (Yayımlanmamış yüksek lisans tezi). Üsküdar Üniversitesi, İstanbul.

Söner, O., Yılmaz, O. (2020). Ergenlerin sosyal medya beğenilmeme korkularının yordayıcısı olarak benlik saygisı ve benlik tasarımı. 51-68.

Sönmez, E.E., Özgen, E. (2017). Medya kullanımı ve beden imaj1: Türkiye ve İngiltere örneği. Akdeniz İletişim Dergisi,27.78-95.

Steinberg, L. (2007). Ergenlik, Yay. Haz., Figen Çok, İstanbul: İmge Kitabevi.

Uğurlu, N., Akın, H., (2008). Muğla sağlık yüksekokulu öğrencilerinin beden-benlik algısı ve psikolojik sıkıntı belirtileri ile ilişkisi. Atatürk Üniversitesi Hemşirelik Yüksekokul Dergisi, 11(4), 38-47.

Uskun, E., Şabaplı, A. (2013). Lise öğrencilerinin beden algıları ile yeme tutumları arasındaki ilişki. TAF Preventive Medicine Bulletin. 12 (5), 519-528.

Vatansever, G. (2014). Stomal hastalarda beden imajı ve benlik saygısı. (Yayınlanmamış Yüksek lisans tezi). Haliç Üniversitesi, İstanbul.

Vogel, E. A., Rose, J. P., Roberts, L. R., \& Eckles, K. (2014). Social comparison, social media, and self-esteem. Psychology of Popular Media Culture, 3(4), 206222. https://doi.org/10.1037/ppm0000047

Yavuzer, H. (2014). Çocuk psikolojisi. İstanbul: Remzi Kitapevi.

Yiğit, H. (2010). Ergenlerin Benlik Saygılarının Yaşam Doyumu ve Bazı Özlük Nitelikleri Açısından İncelenmesi. (Yayınlanmamış yüksek lisans tezi). Selçuk Üniversitesi, Konya.

You, S. Shin, K. Kim, A. (2017). Body 1mage, Self-Esteem, and Depressionin Korean Adolescents. Child Ind Res, 10, 231-245. DOI 10.1007/S12187-016-9385Z 


\section{ETİK ve BİLIMMSEL İLKELER SORUMLULUK BEYANI}

$\mathrm{Bu}$ çalışmanın tüm hazırlanma süreçlerinde etik kurallara ve bilimsel atıf gösterme ilkelerine riayet edildiğini yazar(lar) beyan eder. Aksi bir durumun tespiti halinde Afyon Kocatepe Üniversitesi Sosyal Bilimler Dergisi'nin hiçbir sorumluluğu olmayıp, tüm sorumluluk makale yazarlarına aittir. Yazarlar etik kurul izni gerektiren çalışmalarda, izinle ilgili bilgileri (kurul adı, tarih ve sayı no) yöntem bölümünde ve ayrıca burada belirtmişlerdir.

Kurul adı: Afyon Kocatepe Üniversitesi Sosyal ve Beşeri Bilimler Bilimsel Araştırma Ve Yayın Etiği Kurulu

Tarih: 06.04.2018

No: $2018 / 25$

\section{ARAŞTIRMACILARIN MAKALEYE KATKI ORANI BEYANI}

1. yazar katk1 oran1 : $\% 60$

2. yazar katk1 oranı : $\% 40$ 